\title{
PERGESERAN RELASI ORANG TUA DAN ANAK DALAM PERKARA HUKUM WALI ADLAL
}

\author{
Siti Musawwamah \\ (Jurusan Syari'ah STAIN Pamekasan, jln. Pahlawan km. 04 Pamekasan, \\ email:warga_madura@yahoo.com)
}

\begin{abstract}
Abstrak
Artikel ini merupakan hasil penelitian tentang problema relasional orangtua dan anak dalam perkara-hukum wali adlal. Problema yang bernuansa kekeluargaan ini menjadi dilematik karena kedua pihak saling bersikukuh untuk memertahankan kehendaknya masing-masing yang diklaim sebagai hak asasinya. Orangtua "merasa" memiliki otoritas dalam menentukan jodoh untuk anaknya karena diyakini hak ijbar ada padanya. Sedangkan anak juga merasa memiki hak pilih dan/atau hak menentukan jodoh untuk dirinya yang diyakini sebagai hak dasarnya. Persoalan itu seringkali berlanjut menjadi perkara-hukum yang kemudian harus diselesaikan melalui pengadilan agama. Penelitian ini bertujuan untuk mengeksplorasi dan mengeksplanasi latar belakang pengajuan perkara-hukum wali adlal, pelaksanaan persidangan perkarahukum wali adlal, dan putusan majelis hakim tentang perkarahukum wali adlal di pengadilan agama. Dengan menggunakan pendekatan hukum normatif dan teknik evaluative ex-post facto, penelitian ini menghasilkan temuan berupa proposisi empirik sebagai dasar perumusan teori substantif, yaitu pengajuan perkara-hukum wali adlal merupakan problema yuridis formal pergeseran relasional orangtua dan anak.
\end{abstract}

\footnotetext{
Abstract

This article is a research report concerning parents-children relational problem in a litigation of wali adlal (male next of kin and guardian whose consent is required for the marriage of a girl or woman). This is a consanguinity problem and become problematic since both side tends to firmly defense their own wills. The parents claim that they are authoritative to decide their children marriage mate as they assert ijbar right. Yet, the children insist that it is their basic right to settle on their own marriage-mate. Subsequently, they take legal action at the end through religious court (PA). This study aims at exploring and
} 
explaining background of submission on a litigation of wali adlal, the implementation of procedure of wali adlal litigation, and the judges' verdict on wali adlal litigation in religious court. This also employs normative legal approach and evaluative ex-post facto technique. The findings are empirical proposition as the basic reason of substantive theory formulation, the submission of wali adlal litigation is formal legal problem which is the shift of parent-children relation.

\author{
Kata-kata Kunci \\ wali adlal, wali nasab, wali hakim, orangtua, anak.
}

\title{
Pendahuluan
}

Lembaga perkawinan tidak sekedar merupakan alat pengakuan atau legalisasi hubungan seorang laki-laki dan perempuan (court of law) sebagai suami istri, tetapi sebagai perjanjian yang mengarah pada perwujudan kehidupan berkeluarga (rumah tangga) yang sakînah, mawaddah, wa rahmah dalam ikatan lahir batin yang kokoh, kuat, dan berbobot (mitsâqan ghalîdhan). ${ }^{1}$ Oleh karena itu, terdapat beberapa prinsip yang menjadi keharusan penentuan keabsahan perkawinan, yaitu terpenuhi syarat dan rukun perkawinan: ada calon mempelai (suami dan istri), kesetujuan wali, saksi yang adil dan pelaksanaan ijab kabul. Ketentuan inilah yang menjadi kesepakatan jumhûr ulamâ salaf² yang kemudian diikuti dan dikukuhkan oleh ulama Indonesia sebagaimana tercantum dalam rumusan Kompilasi Hukum Islam (KHI) ${ }^{3}$

Keberadaan wali sebagai rukun perkawinan dalam praktiknya tidak jarang menimbulkan problema relasional antara orangtua

1 Undang-Undang RI Nomor 1 Tahun 1974 tentang Perkawinan (Surabaya: Pustaka Tintamas, 1974), hlm. 2. Selanjutnya disebut UU 1/1974; Lihat juga Presiden RI. Instruksi Presiden RI Nomor 1 Tahun 1991 tentang Kompilasi Hukum Islam (Bandung: Humaniora Utama Press, 1991), hlm. 3. Selanjutnya disebut KHI.

2 Wahbah al-Zuhaylî, Al- Figh al-Islâmî wa adillatuh, Juz IV (Beirut: Dâr al-Fikr, 1989), hlm.36.

3 KHI, Pasal 19: Wali nikah dalam perkawinan merupakan rukun yang harus dipenuhi bagi calon mempelai wanita yang bertindak untuk menikahkannya. Pasal 20: (1) yang dimaksud sebagai wali nikah ialah seorang laki-laki yang memenuhi syarat hukum Islam yakni muslim,aqil dan baligh, (2) Wali nikah terdiri dari: wali nasab dan wali hakim, hlm. 10. 
sebagai wali dan anak perempuan sebagai calon mempelai. Orangtua "merasa" memiliki otoritas dalam menentukan jodoh untuk anaknya karena diyakini hak "ijbar" ada padanya. Sedangkan anak juga merasa memiki hak pilih dan/atau hak menentukan jodoh untuk dirinya yang diyakini juga sebagai hak dasarnya. Jika kedua belah pihak (orangtua dan anak\} sama-sama bertahan pada keyakinan pendiriannya dan tidak ada kerelaan mempertemukannya pada suatu kesepakatan dalam penentuan jodoh maka tidak jarang problema relasi orangtua dan anak akan berakhir di Pengadilan berupa pengajuan perkara-hukum wali adlal yaitu penetapan wali nikah (wali hakim) karena wali nasab (yaitu ayah, sebagai wali calon mempelai perempuan) enggan atau menolak menjadi wali nikah.

Perkawinan sesungguhnya merupakan sebagian sunnatullâh sebagai bentuk relasi antarmanusia. Jalinan relasional itu sekurangkurangnya melibatkan dua entitas keluarga yang bersepakat untuk mempertemukan kedua calon mempelai dalam jenjang pelaminan sebagai awal pembentukan keluarga dalam tatanan kehidupan rumah tangga. Meskipun demikian, kesepatan internal anggota keluarga (terutama wali nasab, ayah, dan sekaligus kepala keluarga) maupun kesepatan eksternal dengan anggota keluarga lain tidak sepi dari persoalan.

Persoalan yang sering terjadi pada awal perjodohan tampaknya harus disenergikan dengan kehendak dan kepentingan pimpinan keluarga (ibu dan, terutama, sang ayah). Karenanya, kearifan para pihak perlu dipertimbangkan. Jika tidak, maka realitas ketidakselarasan pikiran dalam memilih dan kemudian menetapkan calon pasangan hidup akan terus terjadi dalam praksis kehidupan setiap akan mengawali rencana berkeluarga. Ketidaksetujuan ayah, sebagai wali nasab bagi mempelai perempuan, seringkali berujung pada ketegangan dan krisis relasi antara ayah dan anak perempuan.

Secara tegas dan pasti, Hadits swt memberlakukan hukum (sunnatullâh) dalam bentuk perjodohan/perkawinan yang berlaku bagi semua makhluk hidup, bukan hanya bagi manusia saja. Oleh karena itu kendala perjodohan yang berpotensi "menyalahi" sunnatullâh harus diselesaikan juga menurut petunjuk Allah swt. sebagai "penanggung jawab" kehidupan manusia. Dalam istilah lain, dapat dinyatakan bahwa berbagai kendala maupun problema yang "mengancam" keberadaan sunnatullâh haruslah dikesampingkan. Di 
sisi lain, kehidupan berpasang-pasangan bagi manusia yang telah menjadi sunnatullâh itu menjadi dasar dalam pengambilan keputusan untuk mewujudkan keberlanjutan rencana pernihakan. ${ }^{4}$

Berkaitan dengan realitas problema itulah, penelitian ini dilakukan. Tujuannya untuk mengkaji tiga persoalan, yaitu: (1) apa yang melatarbelakangi pengajuan perkara-hukum wali adlal ke pengadilan agama, (2) bagaimana pelaksanaan persidangan perkarahukum wali adlal di pengadilan agama, dan (3) bagaimana putusan majelis hakim pengadilan agama tentang perkara-hukum wali adlal. Jawaban atas tiga persoalan tersebut akan memberi gambaran yang relatif holistik dan komprehensif tentang peristiwa pergeseran relasi orang tua dan anak pada perkara hukum wali adlal yang setiap tahunnya diajukan di Pengadilan Agama Pamekasan.

\section{Relasi Orang Tua dan Anak}

Relasi orang tua dan anak merupakan hubungan nasab. Dalam relasi itu, kedua pihak punya hak dan kewajiban masing-masing. Orang tua berhak dihormati oleh anak-anaknya, dan anak-anak berhak disayangi oleh orang tuanya. Satu bentuk penghormatan anak kepada orang tua adalah menaati perintahnya selama tidak bertentangan dengan ketaatan dengan Hadits. Sementara itu, orang tua sebagai pihak yang lebih tua harus menunjukkan kasih sayangnya kepada anak sebagai pihak yang lebih muda sebagaimana ketentuan dalam Hadits Nabi riwayat al-Turmudzî ra. yang artinya, "Tidak termasuk golongan umatku, mereka yang (tua) tidak menyayangi yang muda, dan mereka yang (muda) tidak menghormati yang tua." 5

Semangat Hadits tersebut adalah mendahulukan pelaksanaan kewajiban dari pada perolehan hak. Orang tua memang seharusnya menyayangi anaknya dalam segala perilakunya, sedangkan anak seharusnya menghormati dan memuliakan orang tuanya. Al-Qur'an telah menjelaskan tentang cara menghormati, berbuat baik, mentaati, dan bertutur kata secara sopan anak kepada orang tua. ${ }^{6}$ Sedangkan kedua orang tua, terutama ibu telah mengawali kewajibannya dengan

\footnotetext{
4 Lihat al-Qur’an, Yâsîn (36): 36, Fâthir (35): 11, dan al-Dzâriyat (51): 49.

5 Al-Shan'any, Subul Al-Salam. (Beirut: Dâr al-Fikr: tanpa thn), HR Turmudzi No. 1842, hlm. 304.

6 Lihat al-Qur`an, al-Isrâ' (17): 23.
} 
memberikan kasih sayang kepada anaknya sejak masih dalam kandungan. Semua itu merupakan bentuk kasih sayang orang tua kepada anaknya. ${ }^{7}$

Namun demikian, ketaatan itu tidak mutlak. Ketaatan kepada orang tua harus dilakukan selama tidak menyuruh kepada kekafiran, kemusyrikan, dan kemaksiatan. Dalam Hadits yang diriwayatkan oleh Abî Abd al-Rahmmân al-Silmî dari 'Alî ra, bahwa Rasûlullâh saw bersabda: "Tidak berlaku ketaatan untuk hal-hal kemaksiatan kepada Allah, ketaatan itu hanya untuk hal-hal yang baik."8 Perintah orang tua harus ditaati jika tidak menyengsarakan atau mencederai hak-hak kemanusiaan anak. Jika anak merasa disengsarakan dengan perintah orang tua, maka anak berhak menolak. Misalnya, dalam kasus perkawinan, seringkali terjadi perselisihan antara orang tua dan anak dalam penentuan jodoh. Jika orang tua memaksakan jodoh kepada anaknya tanpa memerhatikan kepentingan dan keinginan anaknya, maka hadits yang diriwayatkan oleh al-Bukhârî, Mâlik, Abû Dawûd, dan Imâm al-Nasai dapat dijadikan sebagai dasar pengambilan keputusan. Di dalam Hadits disebutkan bahwa ketika seorang perempuan yang bernama Khansa binti Khidam dipaksa kawin oleh orang tuanya, Nabi saw mengembalikan keputusan itu kepada si anak untuk memilih antara meneruskan atau membatalkan. ${ }^{9}$ Hadits ini difahami bahwa anak memiliki otonomi untuk menentukan jodoh pendamping hidupnya.

Dalam Hadits lain yang diriwayatkan oleh 'Aisyah dinyatakan jika orang tua dan anak berselisih pendapat mengenai perkawinan, maka hakimlah yang harus memutuskan untuk menetapkan wali nikah sebagaimana teks Hadits yang artinya: "Apabila perempuan menikah tanpa ijin walinya maka nikahnya batal. Apabila ia digauli maka ia berhak menerima mahar sebagai penghalalan farjinya. Maka apabila wali mereka enggan (menikahkan) maka pemerintahlah wali bagi mereka yang tidak memiliki wali.10

7 Lihat al-Qur`an, Luqmân (31): 14 dan al-Ahquaf (46): 15.

8 Sulaymân bin al-Asy'ats al-Sijistanî Abû Dawûd, Sunan Abû Dawûd (Beirut: Dar alFikr, t.th.), hlm 302; Abû Muhammad Abd Allâh bin Yûsûf al-Zayla'î, Nashb al-Rayah

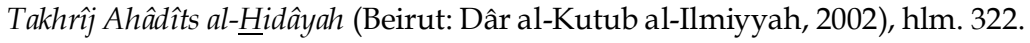

9 Ibid., hlm. 237.

10 Ibid., hlm. 117-118. 
Hadits tersebut dapat dipahami bahwa orang tua tidak berhak memaksa perjodohan anaknya. Jika terjadi peselisihan antara orang tua dan anak tentang penentuan jodoh maka hakimlah yang berhak memutuskannya. Jika benar orang tua mencurahkan kasih sayangnya, maka ia tidak mungkin memaksa anaknya untuk melakukan sesuatu, apalagi hal itu bertentangan dengan kemaslahatan anaknya. Begitu juga sebaliknya, seorang anak tidak akan mudah menentang orang tuanya, jika ia benar-benar ingin memberikan penghormatan kepada orang tuanya. Jadi, kasih sayang dan penghormatan harus dilakukan secara timbal balik. Keluarga yang penuh dengan kasih sayang dan penghormatan satu sama lain adalah keluarga bahagia yang digambarkan oleh al-Qur`an sebagai keluarga yang sakînah, mawaddah dan rahmah.

\section{Kedudukan Wali dalam Perkawinan}

Posisi orang tua sebagai wali dalam perkawinan merupakan rukun yang harus dipenuhi oleh calon mempelai perempuan untuk keabsahan perkawinannya, berdasarkan Hadits Nabi yang diriwayatkan oleh 'Aisyah ra.: "Tidak sah suatu akad nikah, kecuali (dihadiri) wali dan dua orang saksi." 11 Di dalam KHI Pasal 14 dinyatakan: "Untuk melaksanakan perkawinan harus ada: (a) calon suami, (b) calon isteri, (c) wali nikah, (d) dua orang saksi, dan (e) ijab dan kabul", kemudian dipertegas dalam pasal 19 KHI: "Wali nikah dalam perkawinan merupakan rukun yang harus dipenuhi bagi mempelai wanita yang bertindak untuk menikahkannya."12

Mengingat posisi wali nikah sebagai penentu keabsahan status perkawinan, maka ada beberapa syarat yang harus dipenuhi oleh seseorang yang bertindak sebagai wali nikah menurut kesepakatan fuqahâ' yaitu seorang laki-laki muslim, akil, dan baligh.13 Persyaratan itu diikuti oleh fuqahâ' Indonesia dalam tertuang dalam rumusan KHI Pasal 20, yakni, "Yang bertindak sebagai wali nikah adalah seorang laki-laki yang memenuhi syarat hukum Islam yaitu muslim, akil, dan baligh."14 Mengenai syarat laki-laki fuqahâ' berbeda pendapat, Mâlik,

11 Muhammad bin 'Isâ al-Turmudzî, Sunan al-Turmudzî (Beirut: Dâr Ihyâ' al-Turats al-'Arabî, t.th.), hlm. 125.

12 KHI Pasal 14 dan 19, hlm. 6.

${ }^{13}$ Ibn Rusyd, Bidâyat al-Mujtahid, Juz II (Beirut: Dâr al-Fikr: 1960), hlm.12.

14 KHI Pasal 20, hlm. 7. 
Siti Musawwamah

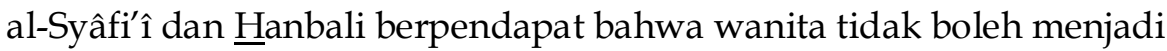
wali dan tidak boleh menikahkan dirinya sendiri. Sebaliknya, Abû Hanîfah berpendapat bahwa wanita boleh menjadi wali nikah dan menikahkan dirinya sendiri. Hanya saja jika calon suami tidak sekufu' wali berhak membatalkan. ${ }^{15}$

\section{Macam-macam Wali Nikah}

Terdapat dua jenis wali nikah, yaitu: Pertama, wali nasab, yakni perwalian yang didasarkan pada hubungan nasab/kekerabatan. Di antara wali nasab ini ada yang mempunyai hak memaksakan kehendaknya untuk mengawinkan seorang gadis yang berada di bawah perwaliannya tanpa meminta ijinnya terlebih dahulu, wali mujbir. Menurut al-Syâfi'î, wali mujbir hanya ayah, kakek dan seterusnya ke atas yang berwenang "memaksakan perwaliannya" bagi perempuan-gadis baik masih kanak-kanak maupun dewasa dan telah memenuhi persyaratan, yaitu: (1) antara wali dan gadis tidak ada permusuhan, (2) laki-laki pilihan wali sekufu' (setara dalam bidang sosial, pendidikan, dan keturunan) dengan gadis yang akan dikawinkan, (3) antara gadis dan calon suaminya tidak ada permusuhan, (4) Maharnya tidak kurang dari mahar mitsil (sepadan dengan martabat dan kedudukan sosial), dan (5) Laki-laki pilihan wali adalah laki-laki yang bertanggung jawab dan penyayang. ${ }^{16}$ Abû Haniffah berpendapat lain, yaitu yang berhak menjadi wali mujbir adalah semua wali nasab dan kewenangannya hanya bagi perempuan belum dewasa atau stress. Sedangkan Hanbalî dan Mâlik berpendapat bahwa yang berhak menjadi wali mujbir hanyalah ayah dan wali lain yang telah mendapat wasiat dari ayah kecuali dalam keadaan sangat terpaksa.

Dalam perundang-undangan di Indonesia, ${ }^{17}$ hak wali mujbir tersebut tidak diakui karena dalam suatu perkawinan dipersyaratkan adanya persetujuan dari kedua calon menpelai. Jika mereka tidak setuju, maka perkawinan tidak dapat dilaksanakan berdasarkan UU No.1 Tahun 1974 pasal 6 ayat (1), KHI pasal 16 ayat (1) dan pasal 17 ayat $(2)^{18}$ Bentuk persetujuan calon mempelai wanita dapat berupa

15 Ibnu Rusyd, Bidâyat al-Mujtahîd, Juz II (Beirut: Dâr al-Fikr: 1960), hlm. 9.

16 Al-Shan'anî, Subul al-Salam, Juz II (Beirut: Dâr al-Fikr, t.th.), hlm. 168.

17 UU 1/1974, hlm. 5.

18 Ibid. Pasal 6 (1), hlm 4 dan KHI Pasal 16 (1) dan 17 (2), hlm. 10. 
pernyataan tegasdan nyata, dengan tulisan, lisan atau isyarat tetapi dapat juga berupa diam dalam arti selama tidak ada penolakan yang tegas. Bila penderita tuna wicara atau tuna rungu persetujuan dapat dinyatakan dengan tulisan atau isyarat yang dapat dimengerti. ${ }^{19}$ Ketentuan tersebut dapat difahami bahwa perkawinan (akad nikah) yang dilaksanakan dengan paksa dapat dibatalkan berdasarkan ketentuan UU.20

Kedua, wali hakim, yaitu perwalian yang timbul karena orang tua mempelai perempuan menolak (adlal) menjadi wali nikah, tidak ada (ghaib), atau sebab lain dan tidak mungkin menghadirkan wali nasab. Dalam KHI disebutkan kategori dan posisi wali. ${ }^{21}$ Kalau seorang perempuan telah meminta ayah kandungnya untuk menjadi wali agar menikahkan dirinya sedangkan walinya keberatan atau menolak (adlal) menjadi wali, maka perempuan itu dapat memperkarakannya kepada Pengadilan Agama untuk mendapatkan penetapan wali hakim, sebagai wali nikahnya. Setelah majelis hakim Pengadilan Agama memeriksa dan memastikan bahwa penolakan wali (ayah kandung) tidak berdasarkan alasan syar'i, maka majelis hakim menetapkan bahwa kewenangan wali nikah pindah kepada wali hakim.

\section{Metode Penelitian}

Penelitian ini menggunakan pendekatan kualitatif yang mengacu pada penelitian hukum sosiologis dengan jenis penelitian evaluative ex-post facto dilakukan dengan cara menelaah dan mengkaji problema perkara-hukum wali adlal mulai dari pengajuan perkara, proses persidangan, hingga produk putusan hukum perkara wali adlal di Pengadilan Agama Pamekasan. Pilihan pendekatan ini dipandang sesuai karena bahan hukum primer pada kajian utama penelitian ini adalah dokumen-dokumen hukum tertulis ${ }^{22}$ berupa sejumlah produk

\footnotetext{
${ }^{19} \mathrm{KHI}$ pasal 16 ayat (2) dan pasal 17 ayat (3), hlm. 10.

${ }^{20}$ UU 1/1974 pasal 27 ayat (1), hlm. 11 dan KHI pasal 71 (f), hlm. 15.

${ }^{21}$ KHI Pasal 21-23, hlm. 10.

22 Noeng Muhadjir, Metodologi Penelitian Kualitatif (Yogyakarta: Rake Sarasin, 1989), hlm 25; Soejono \& Abdurrahman, Metode Penelitian Hukum (Jakarta: Rineka Cipta 2003), hlm 52; Amiruddin \& Zainal Asikin, Pengantar Metode Penelitian Hukum (Jakarta: PT RadjaGrafindo Persada, 2004), hlm. 22.
} 
putusan hakim tentang perkara-hukum wali adlal, arsip pengajuan perkara, statistik perkara yang diterima dan diputus pengadian, dan laporan tahunan yang diterbitkan oleh Pengadilan Agama Pamekasan. ${ }^{23}$ Penelitian ini merupakan kajian isi yurisprudensi. ${ }^{24}$

Penggunaan evaluative ex-post facto dipandang relevan karena pada penelitian ini: (a) dikaji dan dievaluasi fakta hukum yang telah terjadi, (b) tidak dilakukan treatment, (c) kinerja majelis hakim dievaluasi dalam penerapan norma hukum, kaidah-kaidah hukum, dan aturan perundang-undangan yang menjadi pertimbangan dan landasan hukum majelis dalam memutus perkara pada dokumen yang telah diterbitkan, dan (d) dikaji tentang kesesuaian antara dokumen putusan hakim dan kenyataan tentang rasa keadilan subjek hukum.

Penelitian ini menggunakan orientasi teoretik verstehen paradigm, yaitu suatu perspektif subjektif tentang pengertian interpretatif atas pemahaman fakta, makna, peristiwa dan keterkaitannya dalam situasi tertentu, termasuk di dalamnya adalah produk pikiran manusia dalam bentuk tertulis. ${ }^{25}$ Data dihimpun dari dua sumber, yaitu data sekunder berupa dokumen tercetak dan data tersier berupa informasi penunjang. Dokumen tercetak meliputi sejumlah produk putusan hakim tentang perkara-hukum wali adlal. Sedangkan informasi penunjang meliputi arsip pengajuan perkara dan statistik perkara yang diterima dan diputus pengadian, dan laporan tahunan yang diterbitkan oleh Pengadilan Agama. Dalam penelitian ini digunakan tiga jenis bahan hukum, yaitu bahan hukum primer, bahan hukum sekunder, dan bahan hukum tersier.

Data dikumpulkan dengan metode noninteraktif, yaitu pengumpulan data diarahkan pada akumulasi isi dokumen, arsip, maupun data statistik tentang perkara-hukum wali adlal yang tersedia dan/atau diterbitkan oleh pengadilan Agama. Data dokumentasi yang menjadi fokus perhatian utama adalah sejumlah produk putusan majelis hakim tentang perkara-hukum wali adlal yang telah

23 Departemen Kehakiman RI, Laporan Tahunan Pengadilan Agama Pamekasan (Pamekasan: PA, 2006).

24 Soerjono Soekanto, Pengantar Penelitian Hukum (Jakarta: UI Press, 1986), hlm. 42; Soejono \& Abdurrahman, Metode Penelitian Hukum.. hlm. 23.

${ }^{25}$ Moleong, LJ., Metodologi Penelitian Kualitatif (Bandung: Remaja Rosdakarya, 1990), hlm. 20. 
memiliki kekuatan hukum tetap, sedangkan dokumen lainnya diperlakukan sebagai pendukung atau penguat data tentang produk putusan. ${ }^{26}$ Data dianalisis dengan teknik content analysis pada dokumen utama dan dokumen penunjang. Analisis ini dilakukan melalui proses pelacakan dan pengaturan secara sistematik atas tematema konseptual dan indikator yang menjadi fokus perhatian penelitian yang terdapat dalam dokumen. ${ }^{27}$

\section{Hasil Penelitian dan Pembahasan}

\section{Latar Belakang Pengajuan Perkara.}

Wali dalam perkawinan merupakan rukun yang harus dipenuhi bagi calon mempelai perempuan yang bertindak untuk menikahkannya. Apabila tidak dipenuhi, maka status perkawinannya tidak sah. ${ }^{28}$ Dalam praktiknya posisi wali sebagai rukun perkawinan seringkali menimbulkan problema relasi antara orang tua dan anak, sehingga terjadi pengajuan perkarahukum wali adlal. Berdasarkan temuan hasil penelitian, latar belakang pengajuan perkara-hukum wali adlal karena wali pemohon enggan (tidak bersedia) menjadi wali nikah disebabkan oleh: (1) ketersinggungan wali, (2) dijodohkan secara sepihak, (3) hamil di luar nikah, (4) ketidaksetujuan tanpa alasan logis, dan (5) calon suami tidak punya pekerjaan tetap. Temuan tersebut menunjukkan bahwa hubungan relasional orang tua dan anak telah direduksi oleh kepentingan masing-masing pihak. Orang tua yang seharusnya menyayangi anak telah berubah mejadi memaksakan kehendaknya tanpa mempertimbangkan kepentingan anak. Sebaliknya, anak yang seharusnya menghormati orang tua berubah menjadi melawan orang tua dengan mengabaikan keinginannya.

Dalam penelitian ini terdapat pemohon yang sudah dua kali mengajukan perkara-hukum wali adlal. Yang pertama dicabut

26 Untuk memastikan kebenaran isi dokumen dilakukan konfirmasi kepada para hakim yang biasa memeriksa dan memutus perkara hukum wali adlal

27 Hadari Nawawi, Metode Penelitian Bidang Sosial (Yogyakarta: Gadjah Mada University Press, 1983), hlm. 32.

${ }^{28}$ Lihat Hadits Nabi yang diriwayatkan oleh 'Aisyah ra., dalam al-Shan'anî, Subul alSalam (Beirut: Dâr al-Fikr, t.th.), hlm. 117-118. lihat juga KHI Pasal 14, hlm. 9. 
karena ada kesepakatan damai, wali merestui laki-laki pilihan pemohon. Kenyataannya, wali ingkar janji dan mengawinkan pemohon dengan laki-laki pilihan wali. Akibatnya, pemohon mengajukan perkara-hukum wali adlal yang kedua karena pemohon tetap berkeinginan melaksanakan perkawinan dengan laki-laki pilihannya. Karena alasan keengganan wali tidak berdasarkan hukum, maka majelis hakim menetapkan wali pemohon sebagai wali adlal dan menunjuk Pejabat Kantor Urusan Agama Kecamatan Pademawu sebagai wali hakim.

Dalam perspektif hukum Islam, jika orang tua memaksakan jodoh anaknya tanpa memperhatikan kepentingan dan keinginan anaknya, maka Hadits yang diriwayatkan oleh alBukhârî, Mâlik, Abû Dawûd, dan al-Nasa'î dapat dijadikan sebagai dasar pengambilan keputusan untuk mengenyampingkan persetujuan wali nasab. ${ }^{29}$ Dapat difahami bahwa anak memiliki kemandirian untuk menentukan jodohnya. Jika orang tua dan anak berselisih pendapat mengenai perkawinan, maka hakimlah yang harus memutuskan untuk menetapkan wali nikah. ${ }^{30}$

\section{Pelaksanaan Persidangan.}

Persidangan perkara-hukum wali adlal tetap diberlangsungkan karena: (1) pemohon mempertahankan isi permohonan meskipun Majelis Hakim telah menasihati untuk membatalkan dan/atau mencoba terus berusaha untuk memperoleh persetujuan wali, (2) pemohon bersikukuh dengan telah menghadirkan calon suami, saksi-saksi keluarga dan buktibukti surat dari KUA yang pada pokoknya memperkuat dalil permohonan pemohon, dan (3) kehadiran maupun ketidakhadiran wali dalam persidangan tidak mempengaruhi pelaksanaan persidangan.

Temuan hasil penelitian tersebut menunjukkan bahwa posisi pemohon memang sangat kuat sehingga semua isi permohonan dapat dikabulkan oleh majelis hakim. Pemohonlah yang mempunyai hak untuk mengajukan saksi, baik dari calon suami maupun dari saksi keluarga. Bahkan jika dimungkinkan

${ }^{29}$ Al-Shan'anî, Subul al-Salam, hlm. 237

30 Ibid., hlm. 117-118. 
saksi yang diajukan adalah saksi yang sangat berpihak dan menguntungkan pada pemohon, tidak harus dari saksi keluarga. Hal penting yang harus dilakukan saksi adalah bisa memberikan keterangan di bawah sumpah bahwa antara pemohon dan calon suami tidak ada hubungan darah, hubungan sesusuan dan tidak ada halangan untuk melangsungkan pernikahan serta calon suami telah siap untuk menjadi suami pemohon. Posisi wali pemohon hanya sebagai pihak yang jika datang akan diberi kesempatan untuk menyampaikan klarifikasi atas penolakannya menjadi wali dan jika tidak datang maka majelis hakim akan memutuskan bahwa ketidakhadiran wali sebagai isyarat bahwa wali telah melepaskan haknya sebagai wali nikah.

Alasan keengganan wali menjadi wali nikah dalam penelitian ini disebabkan pemohon: (1) bepergian bersama calon suami tanpa seizin walinya, (2) telah dijodohkan dengan laki-laki pilihan wali, (3) hamil di luar nikah, (4) tidak disetujui kawin tanpa alasan yang logis, dan (5) dilarang kawin dengan calon suami yang tidak punya pekerjaan tetap. Semua alasan tersebut tidak berdasarkan ketentuan larangan kawin sebagaimana diatur dalam hukum Syar'i, tetapi lebih merupakan alasan subjektif kepentingan wali.

\section{Putusan Majelis Hakim.}

Putusan hakim atas suatu perkara selalu didasarkan pada pertimbangan hukum yaitu pendapat hakim tentang suatu perkara disertai alasan-alasan dan dasar hukumnya. Pertimbangan hakim itu mencakup: (1) gambaran tentang bagaimana hakim mengritisi fakta atau kejadian perkara, (2) penilaian hakim tentang fakta-fakta yang diajukan, (3) hakim memperpertimbangkannya secara kronologis dan rinci setiap item fakta, dan (4) memuat dasar-dasar hukum yang dipergunakan oleh hakim dalam menilai fakta dan memutus perkara, baik hukum tertulis maupun hukum tidak tertulis. Berikut ini contoh putusan perkara-hukum wali adlal nomor 22/Pdt.P/2007/PA. Pmk.

Fakta Hukum. Pemohon sudah dua kali mengajukan perkarahukum wali adlal. Yang pertama dicabut karena ada kesepakatan damai dengan walinya tetapi kemudian walinya ingkar janji. Yang kedua 
pemohon sudah berusaha mengadakan pendekatan untuk memberi pengertian tetapi walinya tetap menolak. Oleh karena antara pemohon dengan calon suami sudah saling mencintai dan telah bertekad untuk tetap melangsungkan perkawinan, maka pemohon mengajukan permohonan penetapan wali nikah.

Pertimbangan Hukum. Pertimbangan hukum majelis hakim sebelum membuat putusan adalah: (1) wali pemohon hadir di persidangan dan menjelaskan keengganannya menjadi wali nikah karena calon suami tidak punya pekerjaan tetap, (2) pemohon mempertahankan isi permohonan meskipun majelis hakim telah menasehati agar membatalkan dan berusaha memperoleh persetujuan wali, (3) pemohon telah menghadirkan calon suami, saksi-saksi keluarga dan bukti-bukti surat dari KUA (kode P1 dan P2) yang pada pokoknya memperkuat dalil permohonan pemohon, (4) pemohon dan calon suami telah cakap hukum, sekufu dan tidak ada halangan menurut hukum untuk melangsungkan pernikahan, dan (5) calon suami menyatakan kesanggupan menjadi dan akan bertanggungjawab sebagai suami.

Dasar Hukum. Dasar hukum yang dipedomani oleh Majelis Hakim untuk menilai fakta hukum dan membuat putusan adalah: (a) posisi wali dalam pernikahan adalah rukun yang harus dipenuhi, (b) penolakan wali untuk menjadi wali nikah akan menghambat pelaksanaan pernikahan, (c) peraturan Menteri Agama RI Nomor 2 Tahun 1987 pasal 2: "Jika wali pemohon harus dinyatakan adlal, maka Pejabat pada KUA setempat ditunjuk sebagai wali hakim bagi pernikahan pemohon," dan (d) Hadits Nabi: "Jika mereka berselisih tentang wali, maka pemerintah adalah wali bagi mereka yang tidak mempunyai wali."

Isi Putusan. Berdasarkan pertimbangan tersebut dan setelah Majelis Hakim berupaya secara maksimal menasihati pemohon untuk melaksanakan pernikahan dengan persetujuan walinya tidak berhasil, maka Majelis Hakim berketetapan bahwa permohonan pemohon cukup beralasan sehingga permohonan pemohon patut dikabulkan. Secara lengkap isi putusan itu sebagai berikut: (a) mengabulkan permohonan pemohon, (b) menyatakan demi hukum bahwa wali pemohon sebagai wali adlal, (c) menunjuk kepala KUA sebagai wali nikah pemohon, dan (d) membebankan biaya perkara kepada pemohon.

Isi putusan tersebut peneliti konfirmasikan kepada hakim yang menyidangkan perkara-hukum wali adlal. Menurutnya, pada prinsipnya putusan hakim berdasarkan: (1) Bunyi teks peraturan perundang-undangan dan Hadits Nabi, (2) pemohon dipandang 
telah memiliki kecakapan bertindak secara hukum sehingga mempunyai hak untuk menentukan jodohnya, dan (3) alasan keengganan menjadi wali nikah tidak dapat dibenarkan menurut hukum syar'î.

Argumen hakim tersebut menunjukkan bahwa putusan majelis hakim atas pengajuan perkara-hukum wali adlal didasarkan kepada: (1) Bunyi teks Hadits Nabi yang diriwayatkan oleh 'Aisyah ra.: "Tidak sah suatu akad nikah, kecuali (dihadiri) wali dan dua orang saksi,"31 (2) KHI Pasal 14: "Untuk melaksanakan perkawinan harus ada calon suami, calon isteri, wali nikah, dua orang saksi, dan ijab dab kabul". Kemudian secara lebih tegas disebutkan dalam KHI pasal 19: "Wali nikah dalam perkawinan merupakan rukun yang harus dipenuhi bagi mempelai wanita yang bertindak untuk menikahkannya,"32 (c) Bunyi teks Hadits Nabi yang diriwayatkan oleh Aisyah r.a.: "jika orang tua dan anak berselisih pendapat mengenai perkawinan, maka hakimlah yang harus memutuskan untuk menetapkan wali nikah,"33 (d) KHI Pasal 23 (1): "Wali hakim baru dapat bertindak sebagai wali nikah apabila wali nasab tidak ada atau tidak mungkin menghadirkannya atau tidak diketahui tempat tinggalnya atau ghaib atau adlal atau enggan, dan ayat (2) dalam hal wali adlal atau enggan maka wali hakim baru dapat bertindak sebagai wali nikah setelah ada putusan Pengadilan Agama tentang wali nikah tersebut," 34 (e) pada umumnya pemohon tergolong seorang yang cakap bertindak hukum sehingga keputusannya untuk memilih jodoh tidak seharusnya diintervensi oleh siapapun termasuk oleh walinya, dan (f) keterangan saksi bahwa hubungan pemohon dan calon suami sekufu, tidak ada halangan menurut hukum untuk melangsungkan pernikahan dan calon suami memiliki pekerjaan serta akan bertanggungjawab sebagai suami.

Argumen hakim atas putusan perkara-hukum wali adlal tersebut menunjukkan bahwa: (a) kedudukan Wali dalam pernikahan merupakan rukun yang harus dipenuhi, (b) penolakan

\footnotetext{
31 Ibid., hlm. 117-118.

32 KHI Pasal 14, hlm. 6.

33 Al-Shan'anî, Subul, hlm. 117-118.

${ }_{34}$ KHI Pasal 23 (1), hlm. 12.
} 
wali untuk menjadi wali nikah akan menghambat pelaksanaan pernikahan, (c) perempuan yang sudah cakap bertindak hukum mempunyai hak memilih jodoh, dan (d) jika wali harus dinyatakan adlal, maka Pejabat pada KUA setempat ditunjuk sebagai wali hakim bagi pernikahan perempuan yang tidak mempunyai wali.

\section{Penutup}

Deskripsi artikel ini diakhiri dengan kesimpulan, yaitu tiga temuan hasil penelitian: (1) latar belakang pengajuan perkara-hukum wali adlal karena wali pemohon enggan menjadi wali nikah. Keengganan tersebut disebabkan: pemohon bepergian bersama calon suami tanpa seizin walinya, telah dijodohkan, hamil di luar nikah; wali tidak setuju tanpa alasan yang logis; dan calon suami tidak punya pekerjaan tetap, (2) pelaksanaan persidangan perkara-hukum wali adlal tetap diberlangsungkan karena pemohon mempertahankan isi permohonan meskipun Majelis Hakim telah menasihati untuk membatalkan dan/atau mencoba terus berusaha untuk memperoleh persetujuan wali, pemohon bersikukuh dengan telah menghadirkan calon suami, saksi-saksi keluarga dan bukti-bukti surat dari KUA yang pada pokoknya memperkuat dalil permohonan pemohon, dan kehadiran maupun ketidakhadiran wali dalam persidangan tidak mempengaruhi pelaksanaan persidangan, dan (3) putusan Majelis Hakim tentang Perkara-Hukum Wali adlal didasarkan pada bunyi teks peraturan perundang-undangan dan Hadits Nabi, pemohon dipandang telah memiliki kecakapan bertindak secara hukum sehingga mempunyai hak untuk menentukan jodohnya, dan penetapan wali adlal disebabkan keengganan menjadi wali nikah tidak dapat dibenarkan menurut hukum syar'i.

Atas dasar temuan itulah, peneliti menyarankan kepada (1) Ketua dan Majelis Hakim Pengadilan Agama Pamekasan agar temuan ini dapat dijadikan informasi-balikan tentang fenomena pergeseran relasi orangtua dan anak dalam bentuk pengajuan perkara-hukum melalui Pengadilan Agama, (2) Kepala-kepala KUA di lingkungan kecamatan dalam kabupaten Pamekasan agar informasi ini dapar dijadikan bahan masukan tentang perkara-hukum wali adlal yang terjadi di Pamekasan, (3) para pihak yang mengajukan dan/atau 
membantu menangani perkara-hukum wali adlal agar mencermati pelaksanaan proses peradilan hingga diterbitkan putusan majelis hakim serta implementasi hasil penetapannya, (4) Para akademisi, kiai/agamawan, pemuka masyarakat, dan pemimpin umat agar informasi tentang peristiwa-hukum wali adlal dikritisi sebagai realitas faktual tentang pergeseran relasi orangtua dan anak dalam lingkungan rumah tangganya yang diselesaikan melalui jalur peradilan agama serta ekses-ekses yang timbul dalam kehidupan sosiokultural dan sosioreligius; dan (5) Para peneliti dan pemerhati problema sosial kemasyarakatan khususnya dosen-dosen fakultas/jurusan Syariah, sebagai hasil kajian tentang pergeseran relasi orangtua dan anak yang diselesaikan melalui jalur peradilan agama dan penyelesaiannya secara yuridis.

\section{Daftar Pustaka:}

Amiruddin dan Asikin, Zainal. Pengantar Metode Penelitian Hukum. Jakarta: PT RadjaGrafindo Persada, 2004.

Dawûd, Sulaymân bin al-Asy'ats al-Sijistanî Abû. Sunan Ab̂̂ Dawûd. Beirut: Dâr al-Fikr, t.th.

Departemen Agama RI. Al-Quran dan Terjemahnya. Jakarta: Proyek Pengadaan Kitab Suci Al-Quran, Depag RI., 1985.

Departemen Kehakiman RI., Laporan Tahunan Pengadilan Agama, Pamekasan: Pengadilan Agama, 2006.

Manan, Abdul. Penerapan Hukum Acara Perdata di Lingkungan Peradilan Agama. Jakarta: Prenada Media, 2005

Moleong, L.J. Metodologi Penelitian Kualitatif. Bandung: Remaja Rosdakarya, 1990.

Muhadjir, Noeng. Metodologi Penelitian Kualitatif. Yogyakarta: Rake Sarasin, 1989.

Nawawi, Hadari. Metode Penelitian Bidang Sosial. Yogyakarta: Gadjah Mada Univ. Press, 1983.

Presiden RI. 1974. Undang-Undang RI Nomor 1 Tahun 1974 tentang Perkawin-an. Surabaya: Pustaka Tintamas.

Presiden RI. 1975. Peraturan Pemerintah RI Nomor 9 Tahun 1975 tentang Pelaksanaan Undang-Undang RI Nomor 1 Tahun 1974 tentang Perkawinan. Surabaya: Pustaka Tintamas. 
Presiden RI. 1989. Undang-Undang RI Nomor 7 Tahun 1989 tentang Peradilan Agama. Surabaya: Pustaka Tintamas.

Presiden RI. 1991. Instruksi Preseiden RI Nomor 9 Tahun 1991 tentang Kompilasi Hukum Islam. Bandung: Humaniora Utama Press.

Rofiq, Ahmad. Hukum Islam di Indonesia. Cetakan III. Jakarta: PT RajaGrafindo Persada, 1998.

Rusyd, Ibnu. Bidâyat al-Mujtahid. Mesir: Musthafâ al-Bâbî al1960

Shan'anî, Muhammad bin Ismâ'îl al-. Subul al-Salam (Beirut: Dâr alFikr, 1960.

Soejono dan Abdurrahman. Metode Penelitian Hukum. Jakarta: Rineka Cipta, 2003.

Soekanto, Soerjono. pengantar Penelitian Hukum. Jakarta: UI Press, 1986.

Turmudzî, Muhammad bin Isâ al-, Sunan al-Turmudzî. Beirut: Dâr Ihyâ' al-Turats al-'Arabî, t.th.

Zaylâ'î, Abû Muhammad Abd Allâh bin Yûsûf al-. Nashb al-Rayah Takhrîj Ahâdits al-Hidâyah. Beirut: Dâr al-Kutub al-Ilmiyyah, 2002.

Zuhaylî, Wahbah al-. Al-Figh al-Islâmî wa adillatuh. Juz VII. Bairut: Dâr al-Fikr, 1989. 